Databases, Revenues, \& Repertory: The French Stage Online, 16801793 - Databases, Revenues, \& Repertory: The French Stage Online, 1680-1793

\title{
Comment - Celebrating Voltaire in the 1760s
}

\section{Logan J. Connors}

Published on: Oct 07, 2020

DOI: $10.21428 / 671 d 579 e .2025 f 7 f 7$

License: Creative Commons Attribution 4.0 International License (CC-BY 4.0). 
If the Seven Years' War (1756-1763), according to Thomas M. Luckett, "precipitated a process by which the theater became more sensitive to popular demand," then one dramatist channeled the public's tastes better than any other: Voltaire. $\underline{1}$ He was so popular during the 1760 s that, as Lauren R. Clay shows, Voltaire was responsible for nearly "one-third of daily ticket sale income" at the Comédie-Française during the seasons of 1760-61, 1761-62, and 1766-67. 2 What Pierre Frantz calls a "Moment Voltaire" was triggered by the philosophe's engagement with contemporary theatrical tastes for the drame (Le Café ou l'Écossaise, 1760) and his staging of French patriotism during wartime (Tancrède, 1760). $\underline{3}$ But also, as Frantz shows, the period was a veritable showcase of Voltaire's career, complete with popular revivals of his early masterpieces from the 1720s and 1730s. The 1760s, which saw Voltaire "at the peak of his popularity" (Clay), saw nothing less than the "canonization" (Frantz) of Voltaire as both a philosophe and homme de théâtre.

For a while, it seems that Voltaire could do no wrong at France's most prestigious stage. He was at the height of an impressive arc during which he surpassed any other dramatic author of the eighteenth century in ticket sales, total performances, and revenue-per-performance. Voltaire, as Luckett points out, virtually saved the ComédieFrançaise from financial ruin with his lucrative tragedies and comedies and his keen ability to tap into current events and polemics. Despite such glaring proof of Voltaire's standing, many historians and literary scholars of the period still refuse to consider the sheer magnitude of Voltaire's moment, even downplaying, in many cases, "the full scope of Voltaire's popularity" (Clay). The three authors in this section each rectify in their own way this critical oversight. With different approaches, they converge on Voltaire's triumphs and ground their conclusions with tight analysis of quantitative data from the new online Comédie-Française Registers Project ( $\underline{\mathrm{CFRP}}$ ). In what follows, I tease out the most crucial points in essays by Luckett, Frantz, and Clay in an attempt to weave together their diverse accounts of Voltaire's rise to fame, his diverse theatrical output, and then, the philosophe's crash in popularity after the French Revolution.

In "Financial Difficulties and Business Strategies at the Comédie-Française during the Seven Years War," Luckett describes the theater's losses and gains in the late 1750s and early 1760s. Luckett, an economic historian of early modern and revolutionary France, proves that the theater's finances were linked to the effect of war and peace on the pocketbooks of Parisian patrons. He also shows that the Comédie-Française's 
emergence from near ruin during the 1760s was catalyzed by internal efforts to control costs, boost ticket sales, and renegotiate debt. Luckett's close analysis of the Comédie-Française's finances and business practices reveals "remarkably democratic" procedures where actors "received equal honoraria and cast equal votes, regardless of their sex or the size of their shares." Luckett paints a vivid picture of the diverse (and sometimes surprising) tasks required of comédiens du roi-roles that reached far beyond the stage and which required them to attend business meetings, vote on new financial schemes, and negotiate production costs directly with investors, suppliers, and governmental agencies.

The theater's "republican" governance, however, came with a cost: even during periods when it lost revenue, such as the four seasons running from 1757 to 1761, the Comédie-Française still paid out its pensions, operating costs, indemnities, new share loans, and a slew of other sums to actors. In short, the theater was partitioning the profits but it was not sharing the costs. Only after a series of reforms in the early 1760s -by adopting, in fact, less "republican" and more corporatist policies, such as reducing indemnities and salaries to employees (dancers, technicians, attendants), increasing the number of performances per week, and changing the repertory to include more polemical and "public-driven" plays—did the theater recover in 1762 from its financial stress.

Luckett highlights Voltaire's pivotal role in helping "return the Comédie-Française to financial stability," attributing this success, in part, to his exploitation of the rivalry between Counter-Enlightenment polemicists (Charles Palissot and Élie-Catherine Fréron, for example) and philosophes, such as Denis Diderot, Claude Adrien Helvétius, and Jean-Jacques Rousseau. Luckett links the wild summer of 1760, which saw both Palissot's Les Philosophes and Voltaire's L'Écossaise appear at the Comédie-Française, to "the financial distress of the war years" when the theater "increasingly exploit[ed] notorious rivalries between public figures to improve ticket sales [...]." This is an interesting materialist nuancing of several recent theories of repertory norms at the Comédie-Française-explanations of the summer of 1760 that ground the events in a longer arc of disagreement between philosophes and anti-philosophes or in largerscale governmental efforts to distract Parisians from the country's string of defeats in the Seven Years' War. $\underline{4}$ Alongside (or perhaps, more important than) any intellectual reasons, Luckett argues, poor finances (linked to war) caused a shift in the repertory to plays with more polemical, and therefore, supposedly more public appeal. 
It is interesting to note that Luckett's thesis on repertory change during war seems to bear out in dramatic criticism. Luckett's economic explanation for the type of drama that hit the boards in 1760 adds another layer to a noticeable shift or disruption in "normative" dramatic criticism from summaries of that dramatic narratives and historical contexts that were depicted on stage to descriptions of the reactions of social actors in response to performed theater. $\underline{5}$ Polemical plays produced new forms of dramatic criticism, which turned the critic's lens to the reception of particular jibes and jokes in, for example, Palissot's Les Philosophes or Voltaire's L'Écossaise. The most patent example of this shift is Fréron's Relation d'une grande bataille, a performativecritique published in the Année littéraire that underscores the boisterous and militarized behaviors of spectators at the first performance of Voltaire's play. $\underline{6}$ In sum, Luckett provides a convincing fiscal explanation for aesthetic and intellectual changes in drama and its criticism during a precise and turbulent period in French literary and social history.

Less convincing, perhaps, is Luckett's inference that the Seven Years' War instigated an unprecedented period of attention to the wishes and whims of spectators by the Comédie-Française. The war most definitely augmented the desire of actors and administrators to please paying customers; however, the history of the ComédieFrançaise is rich with earlier examples of savvy actors and writers tapping into public vogues and popular scandals. For instance, Voltaire, who mastered the art of pleasing eighteenth-century theatre publics, rehashed several of the themes from Marivaux's popular Préjugé vaincu (1746) just a few years later in Nanine, ou le Préjugé vaincu (1749), which went on to become one of his most performed plays at the theater (195 performances). Voltaire knew how to capitalize on an emerging sentimental strand of drama that combined themes from the French comédie-larmoyante with strategies from English and Italian sentimental comedies. But even a generation before that, actors at the Comédie-Française profited from various events in French society-from the perceived easing of religious austerity after Louis XIV's death $\underline{7}$ to the ongoing Querelle between Ancients and Moderns through the Regency years. $\underline{8}$ Several of these examples are different in scope from the scandalous plays of 1760 but they are nonetheless indicative of the Comédie-Française's persistently close watch on Parisian vogues, fads, and disputes.

In his conclusion, Luckett argues that by performing Voltaire's L'Écossaise numerous times throughout the eighteenth century, the Comédie-Française was more liberal and accepting of scurrilous ideas than the royal censors. This is undeniable but a reader 
might infer the argument that the theater was able to disseminate Voltaire's ideology more successfully than print media, given the play's lack of official permission by the crown. Luckett writes, "[t]hough too hot for the French royal censors, L'Écossaise remained a favorite at the Comédie-Française through the end of the old regime, with 127 performances by 1788. Libelle thus achieved a level of toleration on the stage that it did not enjoy in print." As a theater scholar and enthusiast, I would like to believe that theatrical performance exhibited a subversive potency to circumvent censors and spread enlightened ideas to places and people who were held under the thumb of an oppressive, monarchical publishing regime. As several groundbreaking works have demonstrated, however, the Old Regime's censorship rules were neither altogether authoritarian nor particularly well enforced. $\underline{9}$ Versions of Voltaire's play circulated widely in Paris and in the provinces throughout the second half of the eighteenth century. Without claiming any sort of exact science but based on France's mushy censorship rules and vibrant illegal book trade, it would not be unreasonable to argue that many more French subjects read the print version of L'Écossaise than witnessed a performance of the play at France's most hallowed stage. In addition, by stripping L'Écossaise down to its satirical, libelle core, I wonder if Luckett is not fully engaging with aesthetic and dramaturgical reasons for its success, such as Voltaire's astute borrowings from English sentimental comedy (a vogue at the time), the proximity of his characters to the people of contemporary Europe, the innovative double-screen staging technique, $\underline{10}$ or the interesting representation of geopolitics and European financial concerns that were tied to Caribbean conflict. Voltaire's L'Écossaise was a performed drama and not (or at least, not merely) a staged pamphlet.

Luckett's more financially-grounded arguments ring clear; his account of the theater's inner workings is fascinating and his overall thesis that the theater's rise from potential bankruptcy "depended more on controlling costs than on improving ticket sales" is watertight. With close attention to detail and theories grounded in data and in the unique cultural politics of daily operations at the Comédie-Française, Luckett's take on the summer of 1760 allows today's critics to move beyond the reductive "genrebased" explanatory model of repertory change. No longer should scholars assert that there was a gradual replacement of tragedy by comedy or that the tragic genre suffered from lethargy and lack during the eighteenth century. Voltaire's Tancrède (a tragedy) and L'Écossaise (a serious comedy or, arguably, a drame ${ }^{11}$ ) along with Palissot's Les Philosophes (a satire inspired by Molière) all appeared within several months of each other and ultimately form a constellation of public-focused plays with common themes (patriotism, cosmopolitanism, national identity), despite their generic 
and formal differences. Luckett thus reveals a different side of the Comédie-Française and its a cultural program at the time, which spurned reputation, tradition, and grandeur to favor invention, creativity, and concern for contemporary public affairs. All in all, Luckett demonstrates that in 1760, and with Voltaire's artistic vision leading the way, the Comédie-Française was a popular site for inquiry into social anxieties and polemical voices.

According to Frantz, it was Voltaire's strategic positioning in questions of public taste and causes célèbres combined with his deep engagement in the process of playmaking and play selection that helped create an unprecedented "Voltaire Moment." In the 1760s, Voltaire was a prolific and successful dramatist, and it was during this decade, Frantz argues, that he was ultimately canonized as France's most celebrated living legend. Frantz, a scholar of eighteenth-century dramatic literature and theory, integrates quantitative analysis of Voltaire's plays into a fine-grained examination of the literary and theatrical diversity of his dramatic corpus. Voltaire, Frantz shows, excelled at virtually every dramatic project imaginable: he was unrivalled by any eighteenth-century writer in the neoclassical mode (Edipe, Brutus, La Mort de César, among others), in "new" or "Eastern" tragic styles (Zaïre, L'Orphelin de la Chine, Mahomet), in sentimental, genre-bending works (L'Écossaise, Nanine, L'Enfant prodigue), and in the "patriotic genre" (Tancrède, Adélaïde du Guesclin); in sum, he shined in any theatrical vogue at the time. That is not to say that Voltaire never came up short. The plays he penned during the 1770s (Irène, Agothocle, and Sophonisbe) were performed a total of just fifteen times before 1793. This paltry showing of Voltaire's last theatrical works pales in comparison to his unequivocal blockbusters of the 1730s: L'Enfant prodigue (292 performances), Zaïre (229), and Alzire (239) as well as to his more recent successes from the 1760s: Tancrède (174 performances) and L'Écossaise (132). $\underline{12}$

Frantz contends that Voltaire's coronation during his own lifetime as France's most prolific and successful playwright occurred because of both theatrical and extratheatrical factors. Voltaire altered specific plays in order to better tap into popular modes and tastes, and exhibited an almost compulsive desire to please and perfect-an attention to detail that dates back to at least 1718, when he rewrote sections of Fdipe to placate critics of its first performance. During his "moment" in the 1760s, Voltaire included themes from his Amélie, ou le Duc de Foix (penned in the early 1750s) in a reissue of Adélaïde du Guesclin in 1765 and in order to boost the sentimentality of his patriotic play following the Seven Years' War. Also during that decade, Voltaire rewrote sections of his L'Écossaise to better target Fréron and his counter-Enlightenment rag, 
the Année littéraire, in the months after Palissot's Les Philosophes hit the boards at the Comédie-Française.

But perhaps more intriguing is Frantz's argument that Voltaire's theatrical reputation was influenced by his political activities and his public defense of victims. Frantz writes that "l'actualité politise donc le répertoire," and especially when Voltaire's name became synonymous with social justice movements after intervening in the Calas, Chevalier de la Barre, Sirven, and Rochette affairs. It appears that Voltaire's theatrical popularity was a symptom, at least in part, of his politics, whether spectators agreed with his philosophe mission of destroying infâme or despised him for it. The more he defended human rights, a fair judicial system, religious freedom and philosophical inquiry, the more eagerly spectators flocked to the Comédie-Française to see the latest dramatic production or seasoned reprise of France's first intellectual celebrity. Voltaire's reputational oscillation from the political to the theatrical and from the theatrical to the political (for example, in the wake of L'Écossaise), gives a more complete picture of the Patriarch's most heralded decade.

Frantz is more thorough in his teasing out of the build-up to Voltaire's "immense notoriété" than in his section on the philosophe's "disparition au XIX ${ }^{\mathrm{e}}$ siècle." Contrary to Clay's essay, analyzed below, Frantz is more eager to find evidence of nineteenthand twentieth-century continuations of Voltaire's theatrical relevance. Scouring the modern period for evidence of Voltaire, however, is not the goal of Frantz's essay, so he is understandably short on details. It would be interesting to read Frantz's assertions of nineteenth-century integrations and reworkings of Voltaire's plays and dramatic theories as a nice counterbalance to Clay's description of Voltaire's descent, which is a more critically rehearsed narrative. After reading both Frantz's and Clay's essays, one wants to know: did Voltaire find popularity in the nineteenth century in venues other than the Comédie-Française (schools, private theatres, regulated provincial theatres under Napoleon)? How did nineteenth-century writers reinterpret, reinvent, and subjugate Voltaire's prose and dramatic works for new publics? These questions, however, would demand a more comprehensive study. Frantz provides here a succinct cultural history of the "Moment Voltaire"-a narrative of the philosophe's unrivalled theatrical success that "appartient à ce moment historique [...] où toutes les forces sont en phase et entrent en lutte contre un ordre politique et social." As in Luckett's essay, Frantz proves that Voltaire was ultimately responsible for creating a unique social energy in Paris during the 1760s and shows that the Comédie-Française was a dynamic institution of artistic experimentation and cultural risk taking; it was in no way an ossified institution looking back in time for examples of greatness. 
Frantz's main argument should influence editorial norms and eighteenth-century theater scholarship today, so it bears repeating: Voltaire's "moment" was the 1760s. Therefore, plays, such as Adélaïde du Guesclin have a different story in 1765, following the Seven Years' War and in the wake of other successful national tragedies (De Belloy's Le Siège de Calais, for example) than in 1734, when Voltaire first published and performed the work. By destabilizing the timeline of Voltaire's play-by showing that the play had more public impact in the 1760s than when it premiered-Frantz takes to task what he calls the "nouvelle religion théâtro-éditoriale" that seeks to “sacralise le moment d'émergence d'une pièce, c'est-à-dire celui de la première représentation." Rather than focusing on authorship as the primary moment in a play's history, Frantz proposes a more rigorous method for understanding the lived experience of eighteenth-century drama. In many examples from Voltaire's corpus, more Parisians saw his works during the 1760s and at the height of the philosophe's popularity than during their first performance runs. Frantz is thus correct to call into question the authorial birth paradigm as a defining characteristic of any given play; moreover, he provides a compelling thesis for how today's editorial work could be conceptualized with more emphasis on the public import of any given dramatic work. Frantz creates a contemporary space for the eighteenth century's boisterous publics and often-cited culture of theatermania in determining the authoritative version of a play.

Clay's “The Strange Career of Voltaire, Bestselling_Playwright of Eighteenth-Century_ France" is a thick description of Voltaire's popularity during the eighteenth century and of his subsequent fall from favor after the Revolution. Aided by both the $\underline{\text { CFRP }}$ and classic studies on nineteenth-century performances (e.g. Alexandre Joannidès' La Comédie-Française de 1680 à 1900 and Henri Lagrave's Le Théâtre et le Public), Clay, a historian of Old-Regime and revolutionary France, details "the sharp contrast between the exuberant contemporary reception of Voltaire's repertory by the eighteenth-century paying public with his less than glorious 'theatrical afterlife.'” 13 Perhaps most fundamentally, Clay overturns, through her analysis of the ComédieFrançaise's receipts during the second-half of the eighteenth century, the idea that after the Grand siècle's greatness, the tragic genre was eclipsed during the French Enlightenment. Pointing out that "tragedy consistently drew in larger crowds that included spectators willing to spend more for their seats," Clay presents a vivid picture of tragedy's triumph, which was led, of course, by Voltaire. Luckett's observation that tragedies did not have to compete with operas because of their performance days mitigates some of the genre's quantitative dominance; nevertheless, we are still a far 
cry from the traditional story of tragic demise and decline. More to the point, no longer can scholars quibble over Voltaire's dominance in the genre. $\underline{14}$

In addition to confronting décliniste narratives of eighteenth-century tragedy, Clay's essay calls into question several popularity metrics employed by outdated quantitative studies, such as Lancaster's book $\underline{15}$ and Joannidès' La Comédie-Française. $\underline{16}$ Clay contends that by favoring total tallies of performances and by not providing yearly totals of revenue, early efforts to quantify theatrical success significantly "underreport the popular draw of the works of Voltaire." When total author revenue (the total sum of the receipts for any given author across all of his or her works), revenue-per-play, or revenue-per-performance enter the equation, Voltaire matches and often surpasses Corneille, Racine and, at specific moments in the 1760s, Molière-authors whose works appeared decades before Voltaire was even born (and who thus have more time to accumulate total performances). Clay proposes a new metric to gauge eighteenthcentury theatrical success by spurning a cumulative analysis across centuries to reveal instead theatrical flashpoints-particular moments when certain plays or authors garnered tremendous success in a short period of time. Clay provides a quantitative framework that confirms Frantz's thesis about Voltaire's canonization in the 1760s; but also, the flashpoint metric will enable scholars working on other authors to speak more accurately about the import of ephemeral vogues and brief events at the ComédieFrançaise, such as Beaumarchais' marketing efforts before Le Mariage de Figaro, Houdar de La Motte's meteoric rise to fame in the early 1720s, the advent of the comédie larmoyante in the 1730s, and much more.

Clay, like Luckett and Frantz, proves that Voltaire was in a league of his own during the eighteenth century. Also like Frantz, Clay highlights Voltaire's remarkably modern engagement with the process of theater, both at the Comédie-Française, where he "attended rehearsals of new works" and coached "the actors to realize his vision" as well as at his own theater in Ferney, where he staged (and often starred in) early versions of plays that appeared later on the Parisian stage. Also convincing is Clay's explanation of the demise of Voltaire's dramatic corpus, which "declined so sharply in popularity that by the 1850 s performances had become rare." Clay argues that Voltaire's fall from glory was exacerbated by his post-revolutionary reputation as "France's most politically polarizing author." Similar to Frantz, who grounds Voltaire's dramatic successes of the 1760s in his engagement with political causes and victims of infâme, Clay attaches Voltaire's falloff in the nineteenth century to his reputation as a political instigator and critic of religion. Forever associated with the anti-clericalist, violent arm of the Revolution and Terror, Voltaire, according to this account, was 
ostracized by many nineteenth-century critics, pedagogues and artists, who viewed him as little more than a "stand-in for the radical Revolution." This primarily cultural explanation is confirmed by the precipitous drop in performances of Voltaire's works at the Comédie-Française. Clay then argues that, based on that theater's repertory alone, it is clear that by the mid-nineteenth century, "Voltaire-the-playwright, for all practical purposes, was already dead." As in the case of Frantz' article, this reader wonders: given the rapid privatization and expansion of theaters across France and its colonies during the nineteenth century, was the famous philosophe's supposed "death" confirmed in Besançon, Bordeaux, and Béziers? Did spectators continue to enjoy Voltaire's comedies and tragedies in Cahors, Calais, and Carcassonne?

Clay's analysis would undoubtedly be bolstered by furthering the thesis of her breakthrough monograph on privatized regional and colonial theatres into the nineteenth century. $\frac{17}{17}$ What were the effects on Voltaire's corpus of events such as the Chapelier Law in 1791, which deregulated State control of theatres and facilitated an exponential boom in the number of theaters in Paris at the turn of the century? Aside from the socio-political reasons detailed by Clay, what role (if any) did the rise of private theaters in France's capital and elsewhere have in Voltaire's descent from stardom? That complex analysis, however, falls out of the purview of this collection of essays on the Comédie-Française; also, it would require an extensive study of nineteenth-century theater networks and an exhaustive examination of a rather elusive and sporadic corpus. As several recent works have brought to light, research on provincial and colonial theaters before the twentieth century remains an arduous $\operatorname{task} . \underline{18}$

Clay's most salient points about Voltaire's triumph during the eighteenth century-and particularly, in the 1760s, a veritable décennie de Voltaire-are impeccably researched and clearly presented. Clay argues that his unequivocal success at the ComédieFrançaise stemmed from the philosophe's ability to present "a stream of new themes, sets, and costumes, ideas, and intense emotions within a classical framework that both the royal actors and the Parisian public seem to have found pleasingly predictable." This sweeping aesthetic argument might explain Voltaire's tragic dominance although his most popular tragedy and, according to Clay, "the highest-earning play of the era 1700-1789," Zaïre, was a radical departure from the author's previous work. And would spectators really have found L'Écossaise "predictable"? Voltaire's bold use of the drame (a genre that he otherwise critiqued in his correspondence and in other writings) as a defense of the philosophes who were subjected to Palissot's ridicule in 1760 was not predictable; nor did its emotive prose, current events, or international 
character compositions fit nicely "within a classical framework." L'Écossaise is possibly just an anomaly; even so, as Clay points out, in taking in more than 113,000 livres during the 1760s, it was the decade's second highest-earning play.

Clay's inability to fit "all of Voltaire" into a box, however, is understandable. The philosophe "wrote far more than anyone else" in eighteenth-century France, $\underline{19}$ so there is always an exception to any rule we try to pin on him. Voltaire was an enigmatic giant who offered harsh criticism of new genres, popular tastes, and international vogues while at the same time deploying all three at various moments throughout his sixtyyear career. More importantly, Clay most effectively reveals the potential of a digital project, such as the $\underline{\text { CFRP. }}$. While scholars have claimed through anecdotes or in close readings of critics from the time that tragedy prospered during the Enlightenment or that Voltaire was a big deal, Clay offers incontestable proof that the Patriarch of Ferney was not only performed often, but also, that his performances were some of the hottest tickets in town. Her empirical inquiry, combined with a deep, close knowledge of cultural climates in the 1760s, the revolutionary years and the mid-nineteenth century, produces a useful framework for explaining theatrical success at the time as well as a model for scholars to fruitfully and responsibly use a digital resource like the CFRP.

The three essays in this section differ in significant ways: Luckett provides a synchronic, fine-grained account of the financial workings and cultural politics of the Comédie-Française during the late 1750s and early 1760s; Frantz reassesses the very notions of repertory, canon and patrimoine, proving that external elements, such as political events and engagements in social justice, drive ticket sales and determine exactly what it means to be successful at the theater; Clay most fully engages with the $\underline{\text { CFRP }}$ to rescore traditional rankings that she modifies with more detailed accounts of revenue. She proves that Voltaire outperformed seventeenth-century greats at various moments in the eighteenth-century and that the Enlightenment was not, in fact, irreconcilable with tragedy. What links these essays is not only their judicial use of the new $\underline{\text { CFRP }}$ database, but also, their recognition that any understanding of dramatic success, performance norms, or theatrical culture during the French Enlightenment requires serious engagement with Voltaire, a writer who, perhaps unjustifiably, is largely absent from the stage today.

\section{Footnotes}

1. Thomas M. Luckett, "Financial Difficulties and Business Strategies at the

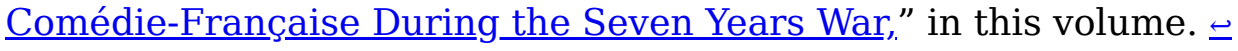


2. Lauren R. Clay, “The Strange Career of Voltaire, Bestselling Playwright of Eighteenth-Century France," in this volume. $\_$

3. Pierre Frantz, "The Voltaire Moment," in this volume. $\triangleq$

4. See, for example, Olivier Ferret, La Fureur de nuire. Échanges pamphlétaires entre philosophes et antiphilosophes (Oxford: Voltaire Foundation, 2007); Didier Masseau, Les ennemis des philosophes. L'antiphilosophie au temps des Lumières (Paris: Albin Michel, 2000); and Darrin M. McMahon, Enemies of Enlightenment: The French Counter-Enlightenment and the Making of Modernity (Oxford: Oxford University Press, 2002).

5. For a more detailed description of this conceptual shift in dramatic criticism during the 1760s, see Logan J. Connors, Dramatic battles in eighteenth-century France: philosophes, anti-philosophes and the polemical theatre (Oxford: Voltaire Foundation, 2012), 161-178.

6. Élie-Catherine Fréron, “Relation d'une grande bataille.” Année littéraire V (Paris: Lejay, 1760): 209-216. It is important to note that the veracity of Fréron's account of the performance is dubious. Nonetheless, the discursive shift in dramatic criticism from the play to the parterre is patent.

7. For example, when the actors brought back Biblical tragedies by Racine that were thought to have fallen out of favor during the King's turn to religion in the 1690s. 8. The Comédie-Française performed tragedies by both Ancients and Moderns in the wake of the Querelle d'Homère in the late 1710s and early 1720s. 9. The critical bibliography on the French book and print media trade is vast and varied. For a concise summary of its major debates, see Raymond Birn, Royal Censorship of Books in Eighteenth-Century France (Stanford: Stanford University Press, 2012). $\longleftarrow$

10. The stage was effectively split into two with a curtain, with the protagonist Lindane's apartment on one side and the café on the other.

11. For a summary of the critical debate on whether or not L'Écossaise is a drame, see Russell Goulbourne, Voltaire, Comic dramatist (Oxford: Voltaire Foundation, 2006); for another opinion, see Connors, Dramatic battles, 113-127. 12. See the CFRP list of Voltaire's plays: $\underline{\text { htp://ui.cfregisters.org/author/5 }} \triangleq$ 
13. Clay borrows this term from Mechele Leon, Molière, the French Revolution, and the Theatrical Afterlife (Iowa City: University of Iowa Press, 2009).

14. Luckett writes: "The choice of genre was tied closely to, but not always determined by, the day of the week. . . . The Paris Opéra, the chief competitor to the Comédie-Française, opened only on Sundays, Tuesdays and Fridays, plus Thursdays during the winter months. . . . Tragedies [at the Comédie-Française] were usually staged on Mondays, Wednesdays and Saturdays, while comedies were done on the other four days of the week. As a result tragedies tended to bring in roughly double the ticket sales of comedies. ..." $\triangleq$

15. Henry Carrington Lancaster, The Comédie-Française (1701-1774): Plays, Actors, Spectators, Finances (Philadelphia: American Philosophical Society, 1951). $€$

16. Alexandre Joannidès, La Comédie-Française de 1680 à 1900 (Paris: Plon-Nourrit, 1901).

17. Lauren R. Clay, The Business of Theater in Eighteenth-Century France and Its Colonies (Ithaca, NY and London: Cornell University Press, 2013).

18. See, for example, the introduction to Philippe Bourdin's Aux origines du théâtre patriotique (Paris: CNRS, 2017); see also Cyril Triolaire, Le Théâtre en province pendant le Consulat et l'Empire (Clermont-Ferrand: Presses universitaires Blaise Pascal, 2012).

19. Nicholas Cronk, "Introduction," The Cambridge Companion to Voltaire (Cambridge: Cambridge University Press, 2009), $3 . \Perp$ 